\title{
Impact of Economic Factors on Life and Non- Life Insurance Development in Albania - A VECM Analysis
}

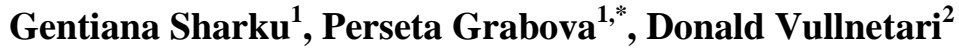 \\ ${ }^{1}$ Department of Finance, Faculty of Economics, University of Tirana, Tirana, 1001, Albania \\ ${ }^{2}$ Department of Economics, Faculty of Economics, University of Tirana, Tirana, 1001, Albania \\ ${ }^{*}$ Corresponding Author: persetagrabova@feut.edu.al
}

Received August 16, 2021; Revised October 18, 2021; Accepted October 29, 2021

\section{Cite This Paper in the following Citation Styles}

(a): [1] Gentiana Sharku, Perseta Grabova, Donald Vullnetari , "Impact of Economic Factors on Life and Non- Life Insurance Development in Albania - A VECM Analysis," Universal Journal of Accounting and Finance, Vol. 9, No. 6, pp. 1280 - 1296, 2021. DOI: 10.13189/ujaf.2021.090608.

(b): Gentiana Sharku, Perseta Grabova, Donald Vullnetari (2021). Impact of Economic Factors on Life and Non- Life Insurance Development in Albania - A VECM Analysis. Universal Journal of Accounting and Finance, 9(6), 1280 1296. DOI: 10.13189/ujaf.2021.090608.

Copyright $\bigcirc 2021$ by authors, all rights reserved. Authors agree that this article remains permanently open access under the terms of the Creative Commons Attribution License 4.0 International License

\begin{abstract}
This paper intends to explore the economic factors which stimulate the demand for insurance products in Albania due to the fact that insurance industry has a significant effect on the economic development of a country. Albania is a developing country and insurance market has progressed moderately. Considering density insurance as a proxy of life and non-life insurance market development, the authors have examined the economic determinants of the Albanian insurance market during the period of 2009-2020 based on quarterly data. The analysis is performed using Vector Error Correction Model designing separate models for each of the insurance segments: life and non-life ones. Among several economic variables, this paper examines the effect of GDP, inflation, real interest rate and unemployment. According to the empirical results, GDP per capita has the most significant impact while unemployment is found to be insignificant in respect to life and non-life insurance density. The results are mostly in accordance with the empirical research work, and they are valuable to both academics and experts in insurance industry. The paper contributes to the existing international literature, especially to the literature related to developing countries, being the first one investigating the influence of a set of economic factors on life and non-life insurance industry in Albania. On the other hand, the results of the paper suggest that insurance companies monitor should evaluate these factors in order to increase should improve insurance service available to the public.
\end{abstract}

Keywords Life Insurance, Non-Life Insurance,
Insurance Density, Economic Factors, Albania, VECM

\section{Introduction}

The role of financial institutions in the economic development of a country has attracted the attention of many researchers who emphasize that financial institutions promote savings and improve the efficiency of capital distribution by directly affecting economic growth rate $[40,41,69]$. The researches in the field of financial intermediation confirm the role of insurance sector in the economic development by promoting financial stability, managing risk more efficiently, promoting employment, facilitating trade, and encouraging loss mitigation. $[25,27,38,53,54,65,68]$. Outreville [53,54] focused on developing countries emphasizing the importance of property-liability insurance and life insurance in the economic growth and development of these countries.

The insurance market in Albania is characterized by significant changes caused from both political changes and rates variations of economic growth. In contrast with developed countries, the life and non-life insurance sector in Albania is still underdeveloped, and significantly below the average of the European Union (EU) member states. On average, in 2019 an EU citizen spent USD 1,300 for the life insurance sector and USD 1,074 for the products of the non-life insurance sector [66]. In 2019, an Albanian 
citizen spent on average USD 56 (the authors' calculation) on insurance products, and only seven percent [1] out of this amount was spent on life insurance products. On the contrary, in developed countries [66], life insurance activity generates more than half of the total gross written premiums. However, in terms of the growth rate of premiums, the progress of the Albanian insurance market is obvious (as described in the next section). Under the conditions when Albania is getting prepared to join EU, it is undergoing major reforms that will reduce financial and political risks, thus affecting economic growth, which will also be reflected in the financial intermediation sector provided by insurance companies.

The aim of this research is to identify the most important economic factors which determine the variance of the demand for life and non-life insurance in Albania using insurance density for life and non-life insurance as proxies of insurance demand. GDP, inflation, real interest rate and unemployment are the factors which have been addressed in the paper. The life and non-life insurance markets in Albania are in the early stages of insurance penetration and to that extent, this study offers insights on the factors influencing insurance demand in Albania.

Abundant international researches provide information about the determinants of the demand for insurance in the world. However, the studies conducted about emerging countries are still few and there are still paths that must be explored. Firstly, this study presents some information on the evolution of both life and non-life insurance sectors providing a comparison within the two sectors. Few studies exist on non-life and life insurance and are mainly focused on OECD countries [11,16], or emerging ones [19] but there are even fewer in Western Balkan countries. Secondly, this research contributes to the existing international literature and mainly that of developing countries with a focus on Albania, one of the Western Balkan countries. Furthermore, the results of this study will help both domestic insurance companies and international ones that are interested in expanding their activity in Albania as well as policy makers in identifying economic factors that promote or hinder the development of life and non-life insurance market in Albania.

In the second section, it is given an overview of the insurance industry in Albania. The third section outlines a literature review regarding the determinants of life and non-life insurance that have been tested in the existing empirical studies. Section four presents the data sources, methodology and empirical results. The final section focuses on the discussion, concluding remarks and suggestions for future work.

\section{Evolution of Albanian Insurance Market}

The first insurance companies in Albania date in the beginning of the twentieth century - almost six centuries later than the first marine insurance contract written in Genova [55]. Insurance activity was performed by branches of foreign insurance underwriters mainly from Italy, but also from England (Lloyd) and France as well. They operated in health and life insurance activity, transport and property insurance etc. After the Second World War, the insurance sector, as all the sectors in a state-planned economy, was part of the state administration. In 1948 the State Insurance Institute was established in order to provide the state insurance of property. In 1949 the Directorate of Saving Desk was established aiming at collecting savings from population. In 1953 the State Insurance Institute and the Directorate of the Saving Desk were merged into a sole institution called the Savings and Insurance Desk Institute. This integration was a nonorganic union due to its specific functions. During the communist period, the insurance market did not progress well. Compulsory insurance dominated and the types of voluntary insurance were scarce. The compulsory insurance for the state property was operated by the decision of the Council of Ministers, while the insurance of private property was accomplished on the basis of the law. All the voluntary insurances were approved by the Ministry of Finance. Thus, the insurance products were provided and supervised only by the state. The Albanian insurance market as in all the Eastern Europe Countries (ECC) was a state monopoly until the end of the 1990s. But, unlike them, Albania was the last country among the EEC where the state lost its monopoly position.

In 1991 the Savings and Insurance Desk Institute got dissolved in two separate entities: The Savings Bank and the Insurance Company (INSIG). INSIG was the only insurance company which operated in Albania until 1999 when the two first private insurance companies were established. So, the state lost its monopoly in the insurance sector while in the bank sector it had lost its monopoly since 1993. Two other insurance companies were licensed and four others in 2004: one of them was a life insurance company which led to the end of the state monopoly on the life insurance activity as well. From 1999 to 2004 the insurance market in Albania progressed moderately. The premium per capita in 1999 and 2004 was respectively USD 4.2 and USD 13.16. The gross written premium to GDP ratio in 1999 and 2004 was respectively $0.38 \%$ and $0.53 \%$.

In 2004, referring to the changes, the Albanian economy was going through in general, and insurance market in particular, the Albanian Parliament approved two laws: the Law no. 9267 dated 29/07/2004 "On the activity of insurance and reinsurance and intermediation on insurance and reinsurance”, and the Law no. 9268 Dated 29/07/2004 “On the organization and functioning of the Insurance Supervisory Authority" (changed in 2014 with Law no. 52). For the first time since then, the 
Albanian insurance market has been regulated by laws designed in line with EU directives and basic principles of the International Association of Insurance Supervisors (IAIS) which would make possible the stabilization and further development of the Albanian insurance market. In 2006, the functions of the Albanian Insurance Authority were transferred to the Albanian Financial Supervisory Authority (AFSA). AFSA consolidated the regulatory and supervisory functions of the financial non-banking activities which were previously carried out by the Insurance Supervisory Authority, the Albanian Securities Commission and the Inspectorate of Supplementary Pensions Private Institutes. The key objectives of AFSA were to promote and foster higher standards in order to protect the consumers and licensees' integrity, to provide stability of the nonbanking financial market and efficiency increase as well as to improve professionalism through continuous enhancement of supervisory and regulatory level in the market. The following years have been intensive and with positive developments towards the accomplishment of the set targets and priorities concerning the development of the supervision, the revision of the legal framework about insurance market and its harmonization with the European directives and international standards as well as the improvement of an appropriate technological system of information with a multiple data base.

The insurance companies which operate in Albania are licensed by AFSA. The insurance companies in Albania carry out insurance activity in accordance with the classes they have been licensed by ASFA and they are not allowed to carry out any other commercial activity. According to the Law no. 52 dated 22.05.2014 "On the activity of insurance and reinsurance" an insurance company, carrying out insurance activity for the classes of the life insurance, is not entitled to perform insurance activity for the non-life classes simultaneously and vice versa.

Until 2011, the insurance market was the largest and most developed market in the non-banking financial sector in Albania. The first investment funds were established in 2012 and the share of insurance sector and investment funds in GDP was respectively $1.6 \%$ and $1.7 \%$ [4]. Due to the enlargement of Investment Funds, during the recent years insurance market has been ranked the third in terms of the share of assets in GDP. According to the Financial Stability Report [4], in 2019, the largest share was held by the commercial banks $(95.5 \%$ of the GDP), followed by the investment funds and the insurance companies which shared respectively 4.3 and $2.2 \%$.

At the end of 2019 the insurance market consisted of twelve insurance companies: eight companies operated in the non-life insurance activity and four companies in the life insurance one. Insurance premiums have continually increased, reflecting a sustainable growth of insurance density and penetration rates. Figure 1 illustrates the evolution of insurance density rates and Figure 2 illustrates the evolution of insurance penetration rates for the total of life and non-life insurance segments.

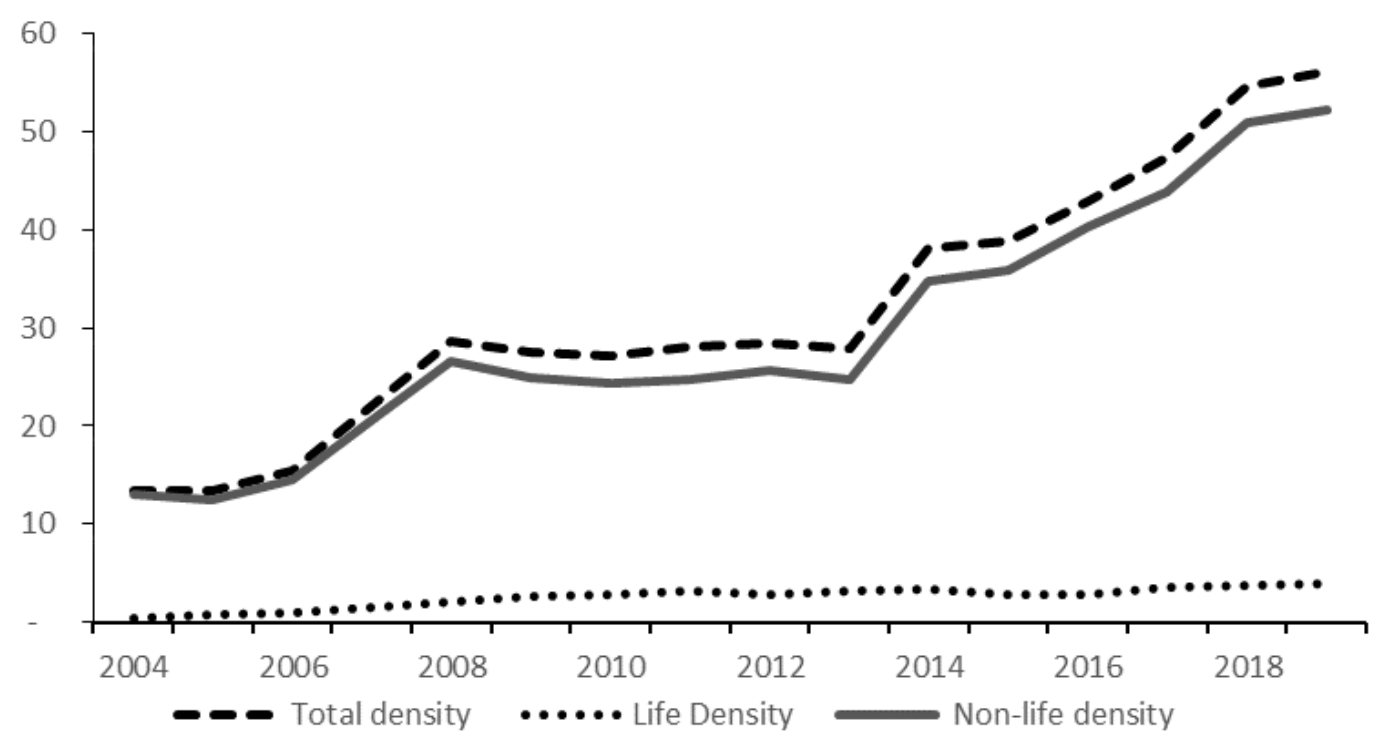

Source: Authors' calculation based on AFSA reports

Figure 1. Evolution of Insurance Density Rates 


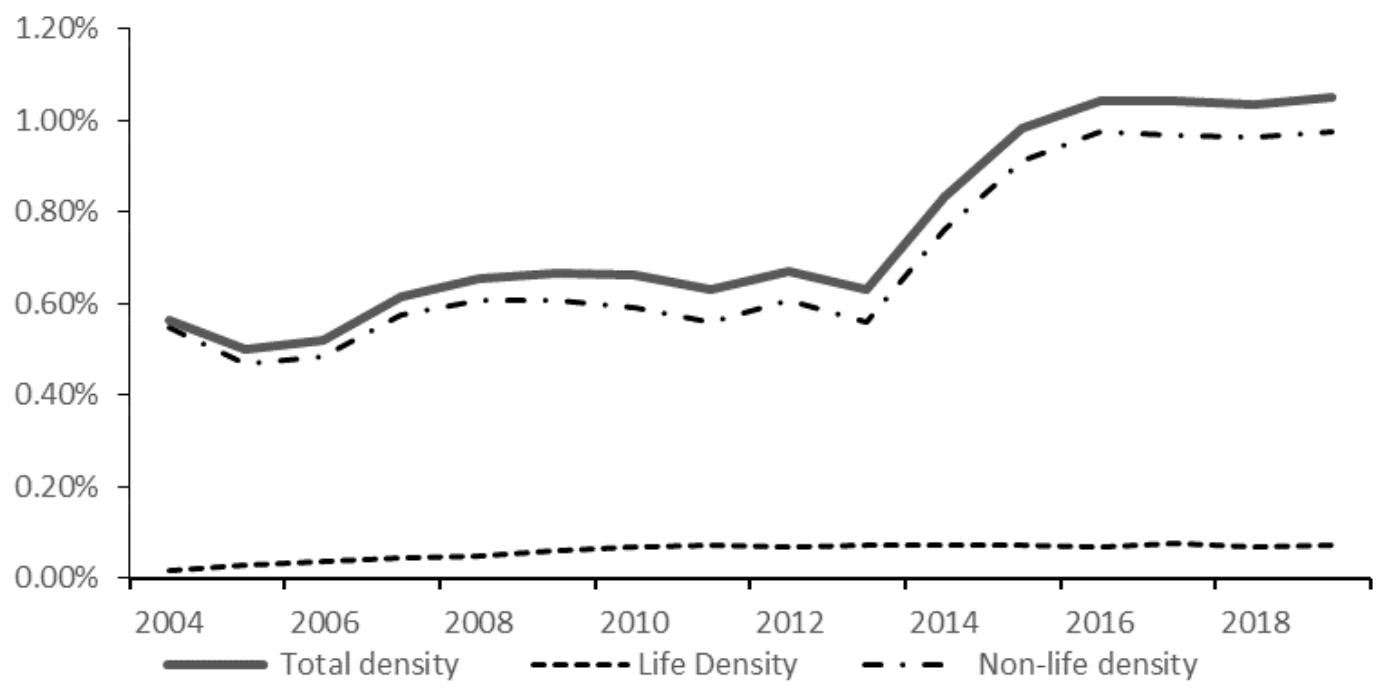

Source: Authors' calculation based on AFSA reports

Figure 2. Evolution of Insurance Penetration Rates

During 2019 the insurance companies collected about USD 160 million, an increase of approximately 4.1\% compared to 2018. This trend is due to the increase of the volumes of gross written premiums by $3.91 \%$ and $6.33 \%$ respectively in the non-life insurance and life insurance segments. The premium per capita was USD 56 (density rate) and the ratio of gross written premiums to GDP (penetration rate) was $1.05 \%$.

Regarding its structure, the market has continued to be oriented towards non-life insurance, which accounts for $93.1 \%$ of the total volume of the gross written premiums in this market. The largest share of life insurance premiums (12\%) is recorded in 2013, due to the large volume of credit accorded by commercial banks up to 2013. During the following years, as the credit level started to decline, the life insurance share started to go down as well.

In 2019, the "Motor third party liability" insurance class held the leading share in gross written insurance premium (64\%), followed by the "Fire and other property damages" (7.86\%). With regard to life insurance, the largest share was held by the "Debtor Life" insurance class (4.39\% of total premium volume).

The foreign capital got involved in the Albanian insurance market too late. For the first time, in 2005 there was a foreign capital participation with approximately $30 \%$ - the foreign capital was represented by $39 \%$ in "INSIG" by IFC and EBRD, and $12 \%$ in "SIGAL" company by the Albanian-American Enterprise Fund. In 2007, the private foreign insurance undertakings from Austria and Greece participated in the Albanian insurance market. During the following years, several mergers and acquisitions have been performed in insurance market which has continuously changed the structure of ownership. At end of 2019, in terms of the capital structure by the country of origin, foreign-owned capital in insurance industry amounted about $45.67 \%$ and originated from Austria.

The structure of insurance market in Albania was changed from a state monopoly (until 1999) to an oligopoly one (up to 2002) and then to a monopolistic competition (during the last decade) [63]. However, the competition degree varies among the classes and activities of insurance market. Comparing life and non-life insurance, the life insurance activity is more concentrated than the non-life insurance one, due to the small number of insurance companies operating in life insurance market.

Comparing compulsory and voluntary insurance, the voluntary insurance market is more concentrated than the compulsory insurance market. Referring to the classes of non-life insurance, the most concentrated market is health insurance, followed by property insurance. The motor insurance market is less concentrated - its structure is of a monopolistic competition type. In 2019, in terms of gross written premium, the five largest companies shared respectively $73.95 \%$ of the total insurance activity, $79.44 \%$ of the non-life insurance activity and $100 \%$ of the life insurance activity.

Despite challenges and issues faced by the Albanian insurance market, recently it has been subject to a positive development trend and it presents a large potential in terms of quality and quantity expansion. This potential is based on the favorable economic conditions, improved regulatory and supervisory system as well as on the business community and population, which are dynamic and easily adaptable.

\section{A Review of the Empirical Studies on Life and Non-Life Insurance Sector}

Due to the importance of the insurance industry in the world economy, the development of insurance industry has attracted the attention of many experts and academics. 
A large part of literature is focused on the factors that drive the development of the insurance market. However, it is observed that the studies are focused mainly on the determinants of the development of the life insurance sector rather than on those of the development of non-life insurance sector. The empirical studies conducted from a macroeconomic perspective are focused on identifying the factors that affect the consumption and development of life and non-life insurance based on cross-sections or panel/single country data $[6,35,72]$. Variables that affect consumption for life and non-life insurance identified in numerous studies can be classified into economic, institutional, demographic, socio-cultural and psychological ones $[6,12,16,19,34,35,56,68,73]$. In addition, there are studies that address the way how consumers benefit from solvency regulations [26].

Some of the variables identified are the same and have the same influence on all the countries, while some studies have concluded with controversial results. This is due to the fact that national insurance markets naturally differ from one another, as each of them is developed under its unique/special environment $[20,68]$.

Given that this empirical research is carried out from a macroeconomic perspective, in this section a review of some empirical studies based on aggregate data is presented mainly focused on the economic factors.

Income has been found to be the most important factor affecting the level of the insurance market development in almost all the previous research work. It is generally accepted that the higher a country's income is, the more affordable the insurance products will be and the higher the demand for both types of insurance will be, life and non-life ones, as the human capital grows at the same time. Furthermore, the authors Lee and Chiu [37] state that the income elasticity of life and non-life insurance premiums are respectively less and larger than 1 , implying that life insurance is a necessary good, and non-life insurance is a luxury good.

Regarding the non-life insurance sector several empirical studies have been compiled about developed countries $[5,8,64,68]$, developing countries $[22,53,59]$ and both developed and developing countries [11,23]. The authors of these studies have found a positive relationship between income measured as GDP per capita or personal income and insurance consumption measured by means of the indicators of insurance penetration and/or density. On the contrary, Dragos [16] who has studied 17 emerging economies from Asia and Europe showed that income has a positive and significant effect on the life insurance sector in CEE countries. However, according to his study, income resulted to be insignificant for the non-life sector in the Asian region. Such a result may be due to the monopolistic structure of China insurance market as defined by Jeng [32]. As Outreville [57] states, the level of additional income can explain people's ability to afford insurance while cultural traits influence people's attitudes and ways of handling perceived risks.
Regarding the life insurance sector, Outreville [54] and Dragos [16] for developing countries, Beck and Webb [6] for developed and developing countries, Hwang and Greenford [30] for selected Asian countries, Celik and Kayali [13] for European countries, Browne \& Kim [12] and $\mathrm{Li}$ et al., [42], for OECD countries, Kjosevski [35], Ćurak and Kljaković-Gašpić [14] for CEE countries and Novović et al., [51] referring to Balkan countries found significant positive relationship between economic development, measured as personal income or GDP per capita and life insurance indicators. Analyzing the demand for life insurance Kjosevski [35] found that a 1\% increase in GDP per capita is accompanied by an increase of about 0.0168 percent points in the penetration of life insurance and USD 1 increase in a person's income level raises the density of life insurance by USD 11.56 .

Inflation is another factor expected to influence the consumption of insurance products. There are few authors who consider inflation as a variable for non-life insurance consumption. It is accepted that inflation has a damping effect on the demand for insurance. Inflation affects non-life insurance by increasing the amount of claims, as it increases the cost of goods and services.

Yuan and $\mathrm{Yu}$ [70], found that fluctuations in non-life insurance premiums are negatively related to the inflation rate while Poposki and Kjosevski [59] found that inflation is not strongly significant. According to Boubaker and Sghaier [9] the impact of inflation depends on the value of inflation rate: during the inflationary periods, non-life insurance premiums are positively related to the interest rate and negatively related to the inflation rate, but in deflationary periods, non-life insurance premiums are negatively related to interest rate and positively related to inflation rate.

Inflation affects life insurance activities through its impact on the returns of investment. However, it has turned out that inflation influences the long-term fixed investments and commitments, including the life insurance contracts more than the short-term investments. Babbel [3] confirmed a negative relationship of inflation the anticipated inflation depresses the value of financial assets and reduces the demand for life insurance products. Babbel [3] showed that even the introduction of price-indexed life products in Brazil was not able to increase the overall demand for life insurance. Many other authors have found inflation to be negatively related to the life insurance consumption $[2,5,12,13,14,35,42,48,54,60,68]$.

Authors of several studies have found that inflation is non-significant for the insurance industry. Focusing on the investigation of factors that influenced the development of insurance industry in four Central European Countries, Brokešová, et al., [10] found inflation to be non-significant for life insurance. Exploring the impact of inflation on life insurance consumption by using time series regression for the period of 1946-1964, Neumann [49] found that inflation has an insignificant effect on life 
insurance consumption. Based on his empirical results, he raised doubts about the industry's claims that inflation hinders the growth of savings through life insurance. A positive relation between inflation and insurance has been found in a few empirical researches. Ehiogu et al., [18] found that inflation increases the level of insurance penetration in Nigeria, although the increase was not significant. Furthermore, Zerriaa et al., [71], concluded that inflation has statistically significant positive influence on life insurance consumption in the MENA region. The authors explained this result by the existence of "monetary illusion", which refers to the tendency of people to think of money in nominal rather than in real terms which is explained by the lack of financial literacy among people living in Mena countries.

As the calculation of insurance premiums is based on the discounted future claim payments, the interest rates are expected to influence insurance premiums and as a result insurance demand. Different authors have used several proxies of interest rates: lending interest rate [6], deposit interest rate, real interest rates, real yield on government bonds [42], discount rate change [36]. Using cointegration techniques Grace and Hotchkiss [24] found a long-run relationship between inflation and interest rate on the insurance underwriting performance in the property liability insurance industry. Lamm-Tennant and Weiss [36] found that discount rates have been significantly related to premium changes in 12 developed countries. By employing data from China, Ling Tian [43] has found a negative effect on the property-liability insurance price.

The prediction of interest rates is important for all the economists, but even more for the life insurers in particular, due to the long-term nature of the life insurance contracts. Regarding life insurance, the results deriving from previous empirical works are different. Beck and Web [6], Elango and Jones [19] confirmed that higher levels of interest rates are associated with higher levels of life insurance consumption. The positive relation between interest rate and insurance demand is explained by the fact that an increase in the interest rate will increase the insurers' incomes from investments. This implies that the prices go down and the demand for insurance products will rise. On the other hand, other studies argue that consumers may reduce their demand anticipating higher interest rates. Analyzing determinants of life insurance consumption in OECD countries $\mathrm{Li}$ et al., [42] found a negative relation between real interest rate and life insurance demand. He argued that households tend to reduce their investment in life insurance without giving up future benefits, converting the policyholder's current consumption in favor of the beneficiaries' policy. Outreville [54] concluded that real interest rates were insignificant for life insurance demand while Sen and Madheswaran [62] found the interest rate significant for life insurance in India but non-significant for it in twelve Asian countries.
There are few empirical studies referring to the assessment of the impact of unemployment rate on insurance demand. The authors Mantis and Farmer [47] have concluded that unemployment affects negatively the demand for life insurance. Outreville [52] declared that on the one hand a high level of unemployment increases risk awareness and the need for life insurance, by increasing the demand for it and on the other hand, an increase in the level of unemployment has a negative effect on the demand for new contracts in the short run. Luciano et al., [44], analyzed the ownership of insurance products by Italians and proved that the demand for life insurance is also strongly related to employment status. This negative relationship between unemployment rate and the demand for life insurance is also confirmed by the studies of Lenten and Rulli [39] and Novović et al., [51] in the Western Balkan countries. Novović et al., [51] confirm that a higher unemployment rate of a country has a negative impact on the demand for insurance, which is justified by the decline in the economic activities and standard of living. Meanwhile Beenstock et al., [7] found a nonsignificant relationship between unemployment and life premiums.

There are very few empirical researches regarding the development of insurance market in Albania, especially relating to the factors that influence the demand for insurance products. Zykaj and Myftaraj-Tomori [74] have explored the impact of some economic and demographic factors on insurance market. It has been found that the only economic factor taken into consideration in the model is the nominal GDP in local currency which has a significant contribution to the insurance market measured in terms of gross written premiums.

\section{Methodology, Data and Empirical Results}

We have analyzed the economic factors that impact life and non-life insurance demand in Albania using a Vector Error Correction Model. Following established procedures, we have conducted the test of relationship between life and non-life insurance with selected economic factors in three stages.

Initially we tested the order of integration in the selected variables. We have used the Augmented Dickey Fuller (ADF) to test for unit roots [15]. The ADF-test includes an autoregressive correction that does not change the asymptotic distribution of the original DF test statistics. In general, macroeconomic time series contain unit roots, and depending on this, the stochastic process has quite different algebraic and statistical properties [50]. If the series are non-stationary or first level integrated ones, we can then test for cointegration.

Secondly, to examine the long-run relationships among the variables we have used cointegration. Based on the 
work of Engle and Granger [21], two or more variables are said to be cointegrated if they are individually integrated, but there exist linear combinations of them which are stationary [58]. Since we have more than two variables, we have used the Johansen [33] cointegration test, which is widely used due to an integrated framework for testing and estimating cointegrating relationships based on the maximum likelihood method, and which determines both the number of cointegrating relationships and the properties of the cointegration vector [50].

Lastly, after establishing the existence and order of cointegration, we have estimated a VECM and examined the cointegrating vector and the speed of adjustments of the parameters. If cointegrating relations are present in a system of variables, the VAR form is not the most convenient model setup as it is useful to consider the specific parameterizations that support the analysis of the cointegration structure, and the resulting models are known as vector error correction models (VECMs) [45]. After estimating the VECM we have interpreted the long-term relationships.

\subsection{Data Selection}

The first dependent variable included in the study is the life insurance density (LID) which is defined as per capita premium expenditure, and it describes how much each inhabitant of a country spends on average on life insurance, expressed in U.S dollars. This measure is used by Beck and Webb [6], Ward and Zurbruegg [68] and Kjosevski [35] in their respective studies on the determinants of life insurance demand.

The second dependent variable is the non-life insurance density (NID) which is defined as per capita premium expenditure and it describes how much each inhabitant of a country spends on average on non-life insurance, expressed in U.S dollars. This measure is used by Pradhan et al., [61], Dragos [16] in their respective studies on the determinants of non-life insurance demand. The data on insurance premiums for life and non- life ones are converted in U.S. dollars for the purpose of comparison. In our regression models, LID and NID are used in the logarithmic form.

The economic factors that we have used as control variables in this study are GDP, inflation, real interest rate and unemployment. The dependent variables, the explanatory variables and the data sources used in our study and the expected signs of the regression coefficients for the independent variables are summarized in Table 1.

Several proxies of incomes are used in researches such as GDP, GNP, national income and personal income. Due to its accessibility GDP is the most common proxy of income in empirical research which is also used in this paper. This indicator is also used in other studies Outreville [54]; Beck and Webb [6]; Elango and Jones [20]; Dragos [16]. GDP per capita (constant 2010 U.S. dollars, fixed prices and non- seasonally adjusted) is the gross domestic product divided by midyear population. It is expected a positive significant relationship between GDP per capita and life and non-life insurance density.

Generally, inflation is defined as "the overall upward price movement of goods and services in an economy". Insurers charge prices today that will be paid for future claims. Therefore, it is necessary to anticipate the inflation rate. Inflation is calculated by several measures such as Consumer Price Index (CPI), the GDP deflator and the core CPI. The majority of the studies take into consideration CPI $[28,42,48,54]$ which is calculated by tracking the prices for a basket of consumer goods and services. A negative correlation between life and non-life insurance demand and CPI is expected.

Referring to Beck and Webb [6], we have used real interest rate calculated as the difference between the nominal interest rate (lending rate) and inflation as measured by the GDP deflator. We expect a negative relationship between real interest rate and life and non-life insurance density in Albania.

The results of the former studies suggest that unemployment has a negative influence on the demand for insurance. Unemployment rate is calculated as a percentage of the total labour force as per the national estimate. Following Outreville [52], Lenten and Rulli [39] and Novović et al., [51] we have used the unemployment rate as a proxy of measuring the effect of unemployment on life and non-life insurance demand. We expect a negative relationship between unemployment rate and life and non-life insurance density in Albania.

Table 1. Definitions of variables

\begin{tabular}{ccc}
\hline Variable name and definition of variables & Source of data & $\begin{array}{c}\text { The expected signs of the regression } \\
\text { coefficients for the independent variables }\end{array}$ \\
\hline $\begin{array}{c}\text { Ln (LID)-Natural logarithm of Life Insurance } \\
\text { Density }\end{array}$ & $\begin{array}{c}\text { National Insurance Supervisory } \\
\text { Authorities and Swiss Re } \\
\text { National Insurance Supervisory } \\
\text { Authorities and Swiss Re }\end{array}$ & \\
$\begin{array}{c}\text { Insurance Density - } \\
\text { Ln (GDPpc)-Natural logarithm of GDP per capita } \\
\text { (current US\$) }\end{array}$ & Albanian Institute of Statistics & Positive \\
INFL- Inflation rate (\%) & Albanian Institute of Statistics & Negative \\
INT- Real interest rate (\%) & Albanian Institute of Statistics & Negative \\
force) (national estimate) & Albanian Institute of Statistics & Negative \\
\hline
\end{tabular}


We have focused on the period from the first quarter of 2009 to the fourth quarter of 2020. Considering the nature of the methods used in time series analysis and the nature of the insurance market in Albania, we included quarterly data, as annual data would mean having very few observations available for an efficient estimation. Although the insurance market was established a long time ago, it began to develop properly only during the last decade.

Table 2 shows the descriptive statistics of the variables considered in the model. As we observe from the data shown in the Table 2, among the dependent variables, non-life insurance density has a higher fluctuation than life insurance density, respectively with a standard deviation of 0.3653 and 0.2071 . Among the independent variables, unemployment has the highest value of standard deviation.

Table 2. Descriptive statistics of variables

\begin{tabular}{ccccc}
\hline Variable Name & Mean & Std. Dev & Min & Max \\
\hline Ln (LID) & 4.4622 & 0.2071 & 3.8895 & 4.8082 \\
Ln (NID) & 6.8403 & 0.3653 & 6.2507 & 7.3572 \\
Ln (GDPpc) & 6.9121 & 0.1246 & 6.6551 & 7.1165 \\
INFL & 2.0972 & 0.8025 & 0.6667 & 4.3667 \\
INT & 4.0172 & 1.3156 & 2.2856 & 6.6982 \\
UNEMP & 14.0383 & 1.9835 & 11.2 & 18.2 \\
\hline
\end{tabular}

\subsection{Results}

First, we used the Augmented Dickey Fuller unit root test to test the stationarity of the variables. Often the raw untransformed time series data used in economics and finance are non-stationary. Testing is needed to determine the integration level to avoid spurious regression. In order to make the series stationary, we have differentiated it [29].

Table 3 reports the results of the ADF unit root test for the included variables for both levels and the first differences. Based on the nature of the data we have also included a deterministic trend. The ADF test shows exactly that all variables are non-stationary at level, but they become stationary at the first-difference level. Hence, all the included variables are I(1), and as such they will be used in the cointegration analysis.

Before performing the Johansen cointegration test it is critical to determine the lag order. Too many lags will affect the small sample performance of the test, while too few lags will imply that the model is not well- specified [29]. There are several criteria to select the optimal lag order. Ventzislav and Lutz [67] show that in general two of them, sequential LR and LM tests do not perform well, especially for small sample sizes. Further, they conclude that for monthly data models, the Akaike Information Criterion (AIC), produces the most accurate results for realistic sample sizes, while for quarterly data the
Hannan-Quinn criterion (HQC) appears to be the most accurate criterion except for sample sizes smaller than 120 , for which the Schwarz Information criterion (SIC) is more accurate.

Table 3. Augmented Dickey Fuller test results for unit roots

\begin{tabular}{ccccc}
\hline & \multicolumn{2}{c}{ Level } & \multicolumn{2}{c}{ Difference } \\
& Intercept & $\begin{array}{c}\text { Trend } \\
\text { and } \\
\text { Intercept }\end{array}$ & Intercept & $\begin{array}{c}\text { Trend and } \\
\text { Intercept }\end{array}$ \\
\hline Ln LID & -1.7856 & -2.9547 & $-6.9766^{* *}$ & $-6.9237^{* *}$ \\
Ln NID & -0.7492 & -1.7163 & $-8.2308^{* *}$ & $-8.1493^{* *}$ \\
Ln GDPPC & -1.6027 & -3.0843 & $-5.9293^{* *}$ & $-5.9984^{* *}$ \\
Unemp & -1.6725 & -1.7725 & $-2.6780^{*}$ & $-3.7624^{*}$ \\
Int & -2.3585 & -0.4899 & $-4.4661^{* *}$ & $-13.5205^{* *}$ \\
Infl & -2.4227 & -3.1237 & $-6.0932^{* *}$ & $-5.9744^{* *}$ \\
\hline
\end{tabular}

** $\mathrm{p}<0.01, * \mathrm{p}<0.05$

As we have a sample of quarterly data and a quite small sample size, we have based the lag order of the SIC, having also HQC and AIC for comparison. For the first model, the SI criteria suggest the use of 1 lag, which is also supported by HQC (Table 4). For the second model the SI criteria suggest again the use of 1 lag, while HQC and AIC suggest the use of 5 lags (Table 5). However, we have based our lag order on the accuracy of SIC and consequently used this lag structure for further estimations.

Table 4. Lag order selection criteria: life insurance density model

\begin{tabular}{cccc}
\hline Lag & AIC & SIC & HQC \\
\hline 0 & 3.863165 & 4.065914 & 3.938354 \\
1 & -1.468277 & $-0.251784^{*}$ & $-1.017142^{*}$ \\
2 & -1.195321 & 1.034916 & -0.368242 \\
3 & -0.94057 & 2.303411 & 0.262455 \\
4 & $-1.880273^{*}$ & 2.377452 & -0.301303 \\
\hline
\end{tabular}

* Indicates lag order selected by the criterion

Table 5. Lag order selection criteria: non-life insurance density model

\begin{tabular}{cccc}
\hline Lag & AIC & SIC & HQC \\
\hline 0 & 3.491562 & 3.696353 & 3.567083 \\
1 & -1.849227 & $-0.620483^{*}$ & -1.396105 \\
2 & -1.584274 & 0.668424 & -0.753549 \\
3 & -1.164142 & 2.112509 & 0.044186 \\
4 & -3.022667 & 1.277938 & -1.436737 \\
5 & $-3.990747^{*}$ & 1.333811 & $-2.027214^{*}$ \\
\hline
\end{tabular}

* Indicates lag order selected by the criterion

The cointegration test was initially established by the work of Engle and Granger [21], and then developed by Johansen [33] to more practical estimation methods. Although different approaches have been developed through the years, Johansen methodology dominates empirical work [29]. Johansen cointegration tests the 
number of cointegration relations in a vector-autoregressive representation. The test and maximum likelihood estimation strategy make it possible to estimate all cointegrating vectors when there are more than two variables [17].

Table 6 and Table 7 represent the results of the Johansen cointegration test for models using life insurance density and non-life insurance density. The results are obtained using both tests: Trace statistic and Maximum Eigen statistic. For the first model, referring to the Trace statistic, results suggest at most 1 cointegration relation, while referring to the Max-Eigen statistic, results suggest at most two cointegration relations. For the second model, referring to the Trace statistic, results suggest at most 1 cointegration relation, while referring to the Max-Eigen statistic, results suggest at most no cointegration relation however at $10 \%$ level, results suggest at most three cointegration relations.

According to Lütkepohl et al., [46] there are differences in small samples, as the trace tests tend to be superior to that of the maximum eigenvalue tests. As we have indeed a small sample, we have based our conclusion on the trace statistic which suggests that for both models there is at most 1 cointegration relation. Hence, we have concluded that there is a long-term relation between the life insurance density and GDP per capita, unemployment, inflation, and interest rate, while the same is true also for non-life insurance density.

As we concluded on the presence cointegration between variables, we continued by estimating a VECM including a cointegration equation. For the first model, estimated VECM, long run equation is as follows:

$\ln (\mathrm{LID})_{\mathrm{t}-1}=15.1782+0.3924 \ln (\mathrm{GDDpc})_{\mathrm{t}-1}-0.0163$ Une

$$
\mathrm{mp}_{\mathrm{t}-1}-0.3026 \text { Int }_{\mathrm{t}-1}+0.1670 \text { Infl }_{\mathrm{t}-1}
$$

All variables in (1) except unemployment are significant at 5\% level. We can observe that a $1 \%$ increase in GPD per capita will lead to a $0.39 \%$ increase in life insurance density. Further, 1 percentage point increase in the real interest rate will lead to a $0.3 \%$ decrease in life insurance density, and a 1 percentage point increase in inflation will lead to a $0.167 \%$ increase in life insurance density.

Table 8 represents the short-run estimates of the VECM. The results show that the previous year deviation of economic growth from the long run equilibrium is corrected in the current period at a speed of $91.6 \%$ and statistically significant a $1 \%$ level. This indicates that the system has a high speed of adjustment towards the long-run equilibrium.

Estimating VECM for the second model, long run equation is as follows:

$$
\begin{gathered}
\ln (\mathrm{NID})_{\mathrm{t}-1}=7.318078+0.4494 \ln (\mathrm{GDDpc})_{\mathrm{t}-1}-0.0122 \\
\text { Unempt-1 - } 0.2383 \text { Intt-1 - } 0.0195 \text { Inflt-1 }
\end{gathered}
$$

In model (2), only two variables are significant at 5\% level, specifically GDP per capita and real interest rate. Here a $1 \%$ increase in GPD per capita will lead to a $0.44 \%$ increase in non-life insurance density. Also, 1 percentage point increase in the real interest rate, will lead to a $0.23 \%$ decrease in life insurance density. Table 9 represents the short-run estimates of the VECM. Even in this case the system has a high speed of adjustment towards the long-run equilibrium. Results show that the previous year deviation of economic growth from the long run equilibrium is corrected in the current period at a speed of $83.8 \%$ and statistically significant a $1 \%$ level.

Table 6. Johansen cointegration test: life insurance density model

\begin{tabular}{cccccc}
\hline $\begin{array}{c}\text { Hypothesized No. of } \\
\text { CE(s) }\end{array}$ & Eigenvalue & $\begin{array}{c}\text { Trace } \\
\text { Statistic }\end{array}$ & p-value & $\begin{array}{c}\text { Max-Eigen } \\
\text { Statistic }\end{array}$ & p-value \\
\hline None & 0.467449 & 81.89267 & $0.0040^{*}$ & 28.98352 & 0.1717 \\
At most 1 & 0.418814 & 52.90916 & $0.0156^{*}$ & 24.96351 & 0.1044 \\
At most 2 & 0.374615 & 27.94564 & 0.0805 & 21.59187 & $0.0431^{*}$ \\
At most 3 & 0.089968 & 6.353777 & 0.6537 & 4.336679 & 0.8222 \\
At most 4 & 0.042902 & 2.017098 & 0.1555 & 2.017098 & 0.1555 \\
\hline
\end{tabular}

* Denotes rejection of the hypothesis at the 0.05 level

Table 7. Johansen cointegration test: non-life insurance density model

\begin{tabular}{cccccc}
\hline $\begin{array}{c}\text { Hypothesized } \\
\text { No. of CE(s) }\end{array}$ & Eigenvalue & $\begin{array}{c}\text { Trace } \\
\text { Statistic }\end{array}$ & p-value & $\begin{array}{c}\text { Max-Eigen } \\
\text { Statistic }\end{array}$ & p-value \\
\hline None & 0.495658 & 86.97264 & $0.0012^{*}$ & 31.48700 & 0.0939 \\
At most 1 & 0.447408 & 55.48564 & $0.0082^{*}$ & 27.28420 & 0.0546 \\
At most 2 & 0.347817 & 28.20145 & 0.0755 & 19.66179 & 0.0792 \\
At most 3 & 0.134425 & 8.539654 & 0.4096 & 6.640608 & 0.5325 \\
At most 4 & 0.040443 & 1.899046 & 0.1682 & 1.899046 & 0.1682 \\
\hline
\end{tabular}

* Denotes rejection of the hypothesis at the 0.05 level 
Table 8. VECM estimates: life insurance density model $^{1}$

\begin{tabular}{cccccc}
\hline & $\mathbf{( 1 )}$ & $\mathbf{( 2 )}$ & $\mathbf{( 3 )}$ & $\mathbf{( 4 )}$ & $\mathbf{( 5 )}$ \\
Variables & $\Delta \mathbf{l n}(\mathbf{L I D})_{\mathbf{t}}$ & $\Delta \mathbf{l n}(\mathbf{G D P p c})_{\mathbf{t}}$ & $\Delta \mathbf{U n e m p}_{\mathbf{t}}$ & $\Delta \mathbf{I n t}_{\mathbf{t}}$ & $\Delta \mathbf{I n f l}_{\mathbf{t}}$ \\
\hline $\mathrm{ECT}_{\mathrm{t}-1}$ & $-0.9160^{* *}$ & $-0.1008^{* *}$ & 0.5349 & 0.1133 & 0.2453 \\
& -0.1699 & -0.0372 & -0.7785 & -0.5329 & -0.8034 \\
\hline$\Delta \ln (\mathrm{LID})_{\mathrm{t}-1}$ & $-0.3545^{*}$ & $0.0512^{*}$ & -0.3716 & $0.8053^{*}$ & 0.0079 \\
& $(0.1213)$ & $(0.0266)$ & $(0.5556)$ & $(0.3803)$ & $(0.5734)$ \\
\hline$\Delta \ln (\mathrm{GDPpc})_{\mathrm{t}-1}$ & $1.0676^{*}$ & -0.1313 & 1.3782 & -1.9808 & -2.1227 \\
& $(0.3497)$ & $(0.1622)$ & $(3.3886)$ & $(2.3195)$ & $(3.4969)$ \\
\hline$\Delta$ Unemp $_{\mathrm{t}-1}$ & 0.0368 & -0.0012 & 0.2404 & -0.0035 & -0.2047 \\
& $(0.0356)$ & $(0.0078)$ & $(0.1633)$ & $(0.1118)$ & $(0.1685)$ \\
\hline$\Delta$ Int $_{\mathrm{t}-1}$ & 0.0811 & $0.0314^{*}$ & -0.0534 & $-0.3556^{*}$ & -0.0507 \\
& $(0.0570)$ & $(0.0115)$ & $(0.2611)$ & $(0.1787)$ & $(0.2695)$ \\
\hline$\Delta$ Infl $_{\mathrm{t}-1}$ & $-0.0705^{*}$ & -0.0132 & 0.0721 & -0.0219 & 0.0396 \\
& $(0.0337)$ & $(0.0096)$ & $(0.2003)$ & $(0.1371)$ & $(0.2067)$ \\
\hline Constant & 0.0180 & $0.0121 * *$ & -0.0237 & $-0.1105^{*}$ & -0.0019 \\
& $(0.0196)$ & $(0.0043)$ & $(0.0897)$ & $(0.0614)$ & $(0.0926)$ \\
\hline Observations & 46 & 46 & 46 & 46 & 46 \\
R-squared & 0.6822 & 0.2372 & 0.0798 & 0.36205 & 0.0395 \\
\hline
\end{tabular}

** $\mathrm{p}<0.01, * \mathrm{p}<0.05$; Standard errors are shown in parenthesis

Table 9. VECM estimates: non-life insurance density model ${ }^{1}$

\begin{tabular}{cccccc}
\hline & $\mathbf{( 1 )}$ & $\mathbf{( 2 )}$ & $\mathbf{( 3 )}$ & $\mathbf{( 4 )}$ & $\mathbf{( 5 )}$ \\
Variables & $\Delta \mathbf{l n}(\mathbf{L I D})_{\mathbf{t}}$ & $\Delta \mathbf{l n}(\mathbf{G D P p c})_{\mathbf{t}}$ & $\Delta \mathbf{U n m e m p}_{\mathbf{t}}$ & $\Delta \mathbf{I n t}_{\mathbf{t}}$ & $\Delta \mathbf{I n f l}_{\mathbf{t}}$ \\
\hline ECT $_{\mathrm{t}-1}$ & $-0.838412^{* *}$ & 0.010015 & -1.132886 & -0.021214 & -0.550749 \\
& $(0.19904)$ & $(0.04463)$ & $(0.83294)$ & $(0.63770)$ & $(0.89118)$ \\
$\Delta \ln (\mathrm{NID})_{\mathrm{t}-1}$ & -0.012621 & 0.033817 & $1.198732^{*}$ & -0.368635 & 0.065492 \\
& $(0.15594)$ & $(0.03496)$ & $(0.65260)$ & $(0.49963)$ & $(0.69823)$ \\
$\Delta \ln (\mathrm{GDPpc})_{\mathrm{t}-1}$ & -0.273845 & -0.202146 & 2.284710 & -0.252863 & -1.623264 \\
& $(0.71563)$ & $(0.16045)$ & $(2.99480)$ & $(2.29282)$ & $(3.20421)$ \\
$\Delta$ Unemp $_{\mathrm{t}-1}$ & $-0.086501^{*}$ & -0.001850 & 0.242701 & -0.005095 & -0.236703 \\
& $(0.04041)$ & $(0.00906)$ & $(0.16912)$ & $(0.12948)$ & $(0.18095)$ \\
$\Delta$ Int $_{\mathrm{t}-1}$ & 0.034606 & 0.011861 & 0.279740 & $-0.516510^{*}$ & 0.019798 \\
& $(0.05001)$ & $(0.01121)$ & $(0.20927)$ & $(0.16021)$ & $(0.22390)$ \\
$\Delta$ Infl $_{\mathrm{t}-1}$ & $0.071283^{*}$ & -0.001853 & 0.013049 & 0.002421 & 0.065504 \\
& $(0.04065)$ & $(0.00979)$ & $(0.18269)$ & $(0.13987)$ & $(0.19546)$ \\
Constant & 0.022661 & $0.011242 *$ & -0.029835 & $-0.119350^{*}$ & -0.001242 \\
& $(0.02063)$ & $(0.00463)$ & $(0.08633)$ & $(0.06609)$ & $(0.09236)$ \\
Observations & 46 & 46 & 46 & 46 & 46 \\
R-squared & 0.368594 & 0.117567 & 0.149904 & 0.262733 & 0.046195 \\
\hline
\end{tabular}

${ }^{* *} \mathrm{p}<0.01, * \mathrm{p}<0.05$; Standard errors are shown in parenthesis

We have run post estimation tests checking for the model stability. Particularly we tested for autocorrelation, normality and heteroscedasticity. The LM test for serial correlation could not reject the null hypothesis of no serial correlation for half of the lags and at $5 \%$ level of significance in both models, suggesting that they have some autocorrelation problems (Appendix 1 \& Appendix 2). The Jarque-Bera test for normality shows that at 5\% level of significance we cannot reject the null hypothesis, thus suggesting that the residuals are normally distributed for both models (Appendix 3 \& Appendix 4). The heteroscedasticity test that at 5\% level of significance we fail to reject the null hypothesis of constant variance, so both models do not suffer heteroskedasticity (Appendix 5 \& Appendix 6). From the tests, we have concluded that the findings of the models are relatively robust. 


\section{Discussion and Conclusions}

The financial system of Albania is a bank-based system, partially due to the inheritance from the past (up to 1991), when the only financial institution familiar to the public was the Savings Bank. Until 1999 the insurance activity was performed by the sole state insurance company. After the licensing of the first private insurance companies (1999), improvement of the insurance legal framework and participation of foreign capital, the insurance market in Albania has gradually progressed. Actually, it is still dominated by the non-life insurance sector, where the "Motor third party liability" accounts for the major part of the total gross written premiums. As the literature suggests, insurance market has a significant role in the macroeconomic activity through: (i) its role in providing security and indemnification; and (ii) its role as an institutional investor [55]. Due to the significance the insurance market has for economic development, this paper has examined some of the economic factors that according to literature would influence the development of the Albanian insurance market. The factors addressed in our paper are: economic growth, inflation rate, real interest rate and unemployment.

Without doubt, economic growth and increase of incomes have a positive impact on both life and non-life insurance market, showing that income is the most significant determinant in the insurance industry. The result is consistent with all the previous empirical work in developed and developing countries. The impact was larger in the non-life segment than in the life insurance one, showing that non-life insurance products are more elastic towards income than life insurance products. It can be explained by the fact that the insurance market in Albania is dominated by non-life insurance products and the "de facto" compulsory nature of life insurance products.

According to Hofflander [28] the anticipated future inflation may change the pattern of insurances purchase, with more term insurance being purchased and less permanent insurance. The consequence will be a smaller volume of premium to the industry. As permanent insurance is almost inexistent in Albania, it is found no negative impact of inflation on life insurance demand. On the contrary, the impact was positive perhaps due to the fact that the greatest part of life insurance constitutes of "Debtor's life insurance" class which is effectively related to the amount of bank credit one gets. Furthermore, the higher the amount of bank credit is, the more it contributes to the development of economic activity. Also, a major part of the gross written premiums is compulsory and thus, the insurance demand is not very sensitive to the changes of inflation. The result is consistent only with few previous empirical studies on life insurance market such as those of Ehigou et al., [18] and Zerriaa et al., [71]. Regarding the non-life insurance market, inflation resulted as insignificant to gross written premiums supporting the findings of Poposki \& Kjosevski, [59] for emerging economies.

The findings of our paper show a negative impact of interest rate on non-life insurance which is in conformity with the observations of previous empirical studies and theory. Negative relationship is found between interest rates and life insurance as well, explained by the fact that unlike the developed countries, life insurance provided by the Albanian insurance companies is of a term insurance type and the investment element is almost inexistent. The result is consistent with some previous empirical studies [31], where it is found that domestic interest rate is statistically significant but inversely related to life insurance consumption, supporting the theory that a rise in real domestic interest rate will divert savings from long-term funds (life premiums) to short-term funds and this would tend to dampen life insurance consumption. According to our model, the impact of interest rate is larger on life insurance activity than on non-life insurance activity, as it is generally agreed that life insurance is more sensitive to interest rates than non-life insurance.

Statistically, unemployment rate resulted to be non-significant referring to life and non-life insurance consumption in Albania. Our findings do not corroborate the earlier studies which show that a higher unemployment rate for a country has a negative impact on the demand for insurance, which is justified by the decline in economic activities and standard of living. One possible explanation may be that the effect of employment on life insurance demand is mainly reflected through the income variable. Furthermore, it can be assumed that employment has maintained an indirect relationship with insurance demand since the development in the insurance market in Albania is not correlated with the unemployment rates which were higher in the beginning of 2000 and then declined when new policies in the insurance market were introduced.

At the end, we have concluded that the results are mostly in accordance with the prior empirical researches. The paper suggests that the insurance companies should monitor and evaluate these factors in order to increase and improve insurance service available to the customers. The results encourage the insurance companies to develop more sophisticated insurance products, especially life insurance policies which may involve some investment elements.

This study considers the insurance density indexes as the proxy of life and non-life insurance consumption. Further studies may be extended to other proxies such as insurance growth index or insurance penetration. When more data become available, it would be useful to take a much bigger sample concerning periods or other determinants such as demographic, institutional and cultural factors which would lead to a greater understanding and knowledge of determinants of life and non-life insurance demand in Albania. 


\section{Appendix}

Appendix 1. VEC LM Test: life insurance density model

\begin{tabular}{lll}
\hline $\begin{array}{l}\text { VEC Residual Serial Correlation LM Tests } \\
\text { Null Hypothesis: no serial correlation at lag order h } \\
\text { Sample: 2009Q1 2020Q4 } \\
\text { Included observations: } 46\end{array}$ & \\
\hline Lags & LM-Stat & Prob \\
\hline 1 & 30.22321 & 0.2160 \\
2 & 20.82711 & 0.7022 \\
3 & 35.43902 & 0.0806 \\
4 & $48.23768 \quad$ Probs from chi-square with 25 df. \\
& & 0.0035 \\
\hline
\end{tabular}

Appendix 2. VEC LM Test: non-life insurance density model

\begin{tabular}{lll}
\hline $\begin{array}{l}\text { VEC Residual Serial Correlation LM Tests } \\
\text { Null Hypothesis: no serial correlation at lag order h } \\
\text { Sample: 2009Q1 2020Q4 } \\
\text { Included observations: 46 }\end{array}$ & \\
\hline Lags & LM-Stat & \\
\hline 1 & 25.80101 & Prob \\
\hline 2 & 42.80543 & 0.4183 \\
3 & 26.59904 & 0.0147 \\
4 & 60.75292 & 0.3762 \\
& & Probs from chi-square with 25 df. \\
\hline
\end{tabular}

Appendix 3. Normality Test: life insurance density model

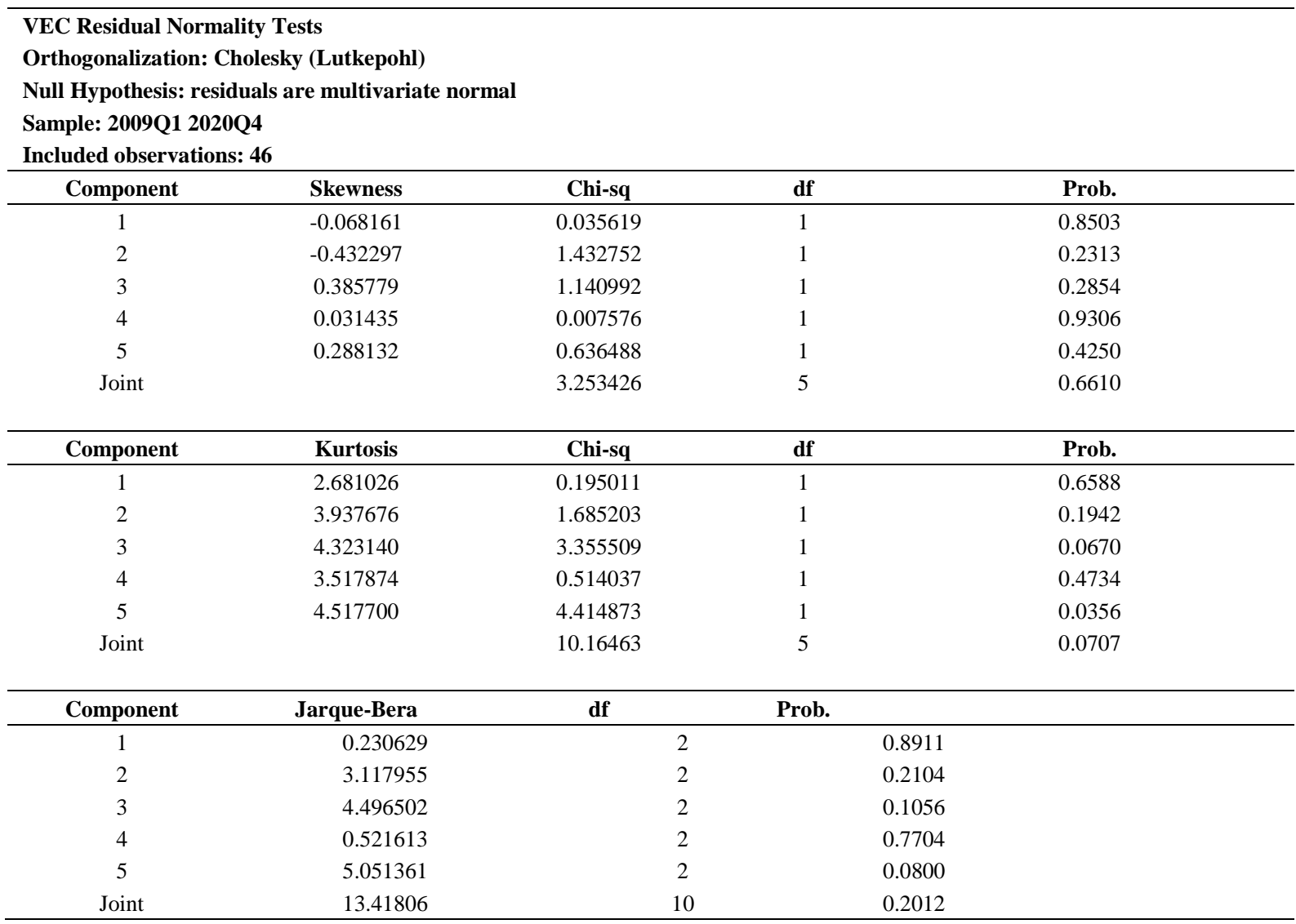


Appendix 4. Normality Test: non-life insurance density model

\begin{tabular}{|c|c|c|c|c|}
\hline \multicolumn{5}{|c|}{$\begin{array}{l}\text { VEC Residual Normality Tests } \\
\text { Orthogonalization: Cholesky (Lutkepohl) } \\
\text { Null Hypothesis: residuals are multivariate normal } \\
\text { Sample: 2009Q1 2020Q4 } \\
\text { Included observations: } 46\end{array}$} \\
\hline Component & Skewness & Chi-sq & df & Prob. \\
\hline 1 & -0.407804 & 1.274999 & 1 & 0.2588 \\
\hline 2 & -0.474645 & 1.727206 & 1 & 0.1888 \\
\hline 3 & -0.179047 & 0.245777 & 1 & 0.6201 \\
\hline 4 & 0.459645 & 1.619767 & 1 & 0.2031 \\
\hline 5 & -0.167567 & 0.215269 & 1 & 0.6427 \\
\hline Joint & & 5.083018 & 5 & 0.4058 \\
\hline Component & Kurtosis & Chi-sq & df & Prob. \\
\hline 1 & 2.483990 & 0.510343 & 1 & 0.4750 \\
\hline 2 & 4.589811 & 4.844374 & 1 & 0.0277 \\
\hline 3 & 3.721100 & 0.996638 & 1 & 0.3181 \\
\hline 4 & 4.230334 & 2.901301 & 1 & 0.0885 \\
\hline 5 & 3.018109 & 0.000629 & 1 & 0.9800 \\
\hline Joint & & 9.253285 & 5 & 0.0994 \\
\hline Component & Jarque-Bera & df & & Prob. \\
\hline 1 & 1.785343 & 2 & & 0.4096 \\
\hline 2 & 6.571580 & 2 & & 0.0374 \\
\hline 3 & 1.242414 & 2 & & 0.5373 \\
\hline 4 & 4.521068 & 2 & & 0.1043 \\
\hline 5 & 0.215898 & 2 & & 0.8977 \\
\hline Joint & 14.33630 & 10 & & 0.1582 \\
\hline
\end{tabular}

Appendix 5. Heteroscedasticity test: life insurance density model

\begin{tabular}{|c|c|c|c|c|c|}
\hline $\begin{array}{l}\text { VEC Residual H } \\
\text { Sample: } 2009 Q 1 \\
\text { Included observa } \\
\text { Joint test: }\end{array}$ & lasticity Tests & s Terms (o & and squa & & \\
\hline Chi-sq & df & \multicolumn{4}{|c|}{ Prob. } \\
\hline 187.1450 & 180 & \multicolumn{4}{|c|}{0.3421} \\
\hline \multicolumn{6}{|c|}{ Individual components: } \\
\hline Dependent & R-squared & $F(12,33)$ & Prob. & Chi-sq(12) & Prob. \\
\hline res1*res1 & 0.312252 & 1.248559 & 0.2938 & 14.36360 & 0.2781 \\
\hline res2*res2 & 0.199591 & 0.685745 & 0.7527 & 9.181207 & 0.6874 \\
\hline res3*res3 & 0.294789 & 1.149539 & 0.3570 & 13.56027 & 0.3297 \\
\hline res $4 *$ res 4 & 0.161294 & 0.528862 & 0.8802 & 7.419536 & 0.8287 \\
\hline res5*res5 & 0.184160 & 0.620760 & 0.8092 & 8.471375 & 0.7473 \\
\hline res2*res1 & 0.176244 & 0.588368 & 0.8356 & 8.107231 & 0.7767 \\
\hline res3*res1 & 0.267040 & 1.001912 & 0.4687 & 12.28386 & 0.4232 \\
\hline res3*res2 & 0.321327 & 1.302024 & 0.2636 & 14.78104 & 0.2536 \\
\hline res4*res1 & 0.337220 & 1.399188 & 0.2154 & 15.51211 & 0.2146 \\
\hline res4*res2 & 0.289047 & 1.118046 & 0.3791 & 13.29615 & 0.3479 \\
\hline res4*res3 & 0.302872 & 1.194754 & 0.3270 & 13.93209 & 0.3051 \\
\hline res5*res1 & 0.271532 & 1.025044 & 0.4499 & 12.49045 & 0.4071 \\
\hline res5*res2 & 0.295173 & 1.151666 & 0.3556 & 13.57795 & 0.3285 \\
\hline res5*res3 & 0.170454 & 0.565067 & 0.8538 & 7.840892 & 0.7974 \\
\hline res5*res4 & 0.231136 & 0.826706 & 0.6231 & 10.63226 & 0.5607 \\
\hline
\end{tabular}


Appendix 61. Heteroscedasticity test: non-life insurance density model

\begin{tabular}{|c|c|c|c|c|c|}
\hline \multicolumn{6}{|c|}{ VEC Residual Heteroskedasticity Tests: No Cross Terms (only levels and squares) } \\
\hline \multicolumn{6}{|c|}{ Included observations: 46} \\
\hline \multicolumn{6}{|l|}{ Joint test: } \\
\hline Chi-sq & df & \multicolumn{4}{|c|}{ Prob. } \\
\hline 192.3980 & 180 & \multicolumn{4}{|c|}{0.2502} \\
\hline \multicolumn{6}{|c|}{ Individual components: } \\
\hline Dependent & R-squared & $\mathrm{F}(12,33)$ & Prob. & Chi-sq(12) & Prob. \\
\hline res1*res1 & 0.243122 & 0.883348 & 0.5713 & 11.18362 & 0.5133 \\
\hline res $2 *$ res2 & 0.445244 & 2.207131 & 0.0358 & 20.48121 & 0.0585 \\
\hline res3*res3 & 0.323734 & 1.316449 & 0.2559 & 14.89178 & 0.2474 \\
\hline res4*res4 & 0.280228 & 1.070655 & 0.4142 & 12.89049 & 0.3771 \\
\hline res5*res5 & 0.270303 & 1.018686 & 0.4550 & 12.43392 & 0.4115 \\
\hline res2*res1 & 0.342599 & 1.433140 & 0.2005 & 15.75956 & 0.2025 \\
\hline res3*res1 & 0.213224 & 0.745275 & 0.6985 & 9.808284 & 0.6328 \\
\hline res3*res2 & 0.364971 & 1.580510 & 0.1459 & 16.78866 & 0.1577 \\
\hline res4*res1 & 0.382892 & 1.706267 & 0.1106 & 17.61301 & 0.1280 \\
\hline res4*res2 & 0.222058 & 0.784969 & 0.6617 & 10.21468 & 0.5971 \\
\hline res $4 *$ res3 & 0.110532 & 0.341736 & 0.9744 & 5.084473 & 0.9551 \\
\hline res5*res1 & 0.206069 & 0.713778 & 0.7274 & 9.479187 & 0.6615 \\
\hline res5*res2 & 0.411040 & 1.919251 & 0.0686 & 18.90786 & 0.0908 \\
\hline res5*res3 & 0.276561 & 1.051287 & 0.4291 & 12.72180 & 0.3896 \\
\hline res5*res4 & 0.214564 & 0.751238 & 0.6930 & 9.869925 & 0.6274 \\
\hline
\end{tabular}

\section{REFERENCES}

[1] AFSA, "Albanian Financial Supervisory Authority Annual Report 2019.” Albanian Financial Supervisory Authority.

https://amf.gov.al/pdf/publikime2/raport/RAPORTI_VJET OR_SHQIP_2019.pdf (accesed April 9, 2021).

[2] Alhassan A., Biekpe N., "Determinants of life insurance consumption in Africa," Research in International Business and Finance, vol. 37, no. C, pp. 17-27, 2016. DOI:10.1016/j.ribaf.2015.10.016

[3] Babbel D., "Inflation, indexation, and life insurance sales in Brazil,” The Journal of Risk and Insurance, vol. 48, no. 1, pp. 111-135, 1981. DOI:10.2307/252655

[4] BOA, “Financial Stability Report-2019.” Bank of Albania. https://www.bankofalbania.org/Financial_Stability/Financi al_Stability_Reports/Financial_Stability_Reports/ (accesed April 9, 2021).

[5] Beck T., Webb I., "Determinants of life insurance consumption across countries.” Policy Research Working Paper, no. 2792, World Bank. https://openknowledge.worldbank.org/handle/10986/15614 (accessed May 15, 2021).
[6] Beck T., Webb I., "Economic, demographic, and institutional determinants of life insurance consumption across countries,” The World Bank Economic Review, vol. 17, no. 1, pp. 51-88, 2003. DOI:10.1093/wber/lhg011

[7] Beenstock M., Dickinson G., Khajuria S., “The determination of life premiums: An international cross-section analysis, 1970-1981,” Insurance: Mathematics and Economics, vol. 5, no. 4, pp. 261-270, 1986. DOI:10.1016/0167-6687(86)90020-X

[8] Beenstock M., Dickinson G., Khajuria S., "The relationship between property-liability insurance premiums and income: An international analysis," The Journal of Risk and Insurance, vol. 55, no. 2, pp. 259-272, 1988. DOI:10.2307/253327

[9] Boubaker H., Sghaier N., "How do the inflation rate and the interest rate affect the non life insurance premiums?," Bulletin Français D’Actuariat, vol. 12, no. 24, pp. 87- 111, 2012. http://www.ressources-actuarielles.net/bfa

[10] Brokešová Z., Pastoráková E., Ondruška T., "Determinants of insurance industry development in transition economies: Empirical analysis of Visegrad Group data,” The Geneva Papers on Risk and Insurance - Issues and Practice, vol. 93, no. 3, pp. 471-492, 2014. DOI:10.1057/gpp.2014.1

[11] Browne M., Chung J., Frees E., "International propertyliability insurance consumption," Journal of Risk and Insurance, vol. 67, no. 1 pp. 73-90, 2000. 


\section{DOI:10.2307/253677}

[12] Browne M. J., Kim K., “An international analysis of life insurance demand," The Journal of Risk and Insurance, vol. 60, no. 4, pp. 616-634, 1993. DOI:10.2307/253382

[13] Celik S., Kayali M. M., "Determinant of demand for life insurance in European countries,” Problems and Perspectives in Management, vol 7, no. 3, pp. 32-37, 2009. https://www.businessperspectives.org/images/pdf/applicati ons/publishing/templates/article/assets/2782/PPM_EN_20 09_03_Celik.pdf

[14] Ćurak M., Kljaković-Gašpić M., "Economic and social determinants of life insurance consumption- Evidence from Central and Eastern Europe,” The Journal of Academy of Business, vol. 16, no. 2, pp. 216-222, 2011. http://www.jaabc.com/Jaabc16-2March2011Curak.html

[15] Dickey D., Fuller W., "Likelihood ratio statistics for autoregressive time series with a unit root," Econometrica, vol. 49, no. 4, pp. 1057-1072, 1981. DOI:10.2307/1912517

[16] Dragos S. L., "Life and non-life insurance demand: The different effects of influence factors in emerging countries from Europe and Asia,” Economic Research-Ekonomska Istraživanja, vol. 27, no. 1, pp. 169-180, 2014. DOI:10.1080/1331677X.2014.952112

[17] Dwyer G. P., “The Johansen tests for cointegration.” Jerry Dwyer.

http://www.jerrydwyer.com/pdf/Clemson/Cointegration.pd f (accesed May 25, 2021)

[18] Ehiogu P., Onyeka E., Sunday N., "Effect of inflation rate on insurance penetration of nigerian insurance industry," International Research Journal of Finance and Economics, vol. 6, no. 170, pp. 66-76, 2018.http://www.internationalre searchjournaloffinanceandeconomics.com/ISSUES/IRJFE _170_05.pdf

[19] Elango B., Jones J., "Drivers of insurance demand in emerging markets,” Journal of Service Science Research, vol. 3, no. 2, pp. 185-204, 2011.DOI:10.1007/s12927-0110008-4

[20] Elango B., Ma Y.-L., Pope N., "An investigation into the diversification-performance relationship in the U.S. Property-liability insurance industry,” Journal of Risk and Insurance, vol. 75, no. 3, pp. 567-591, 2008. DOI:10.1111/j.1539-6975.2008.00275.x

[21] Engle R., Granger C., "Co-integration and error correction: Representation, estimation, and testing,” Econometrica, vol. 55, no. 2, pp. 251-276, 1987. DOI:10.2307/1913236

[22] Esho N., Kirievsky A., Ward D., Zurbruegg R., "Law and the determinants of property-casualty insurance,” Journal of Risk and Insurance, vol. 71, no. 2, pp. 265-283, 2004. DOI:10.1111/j.0022-4367.2004.00089.x

[23] Feyen E., Rodney L., Roberto R., "What drives the development of the insurance sector? An empirical analysis based on a panel of developed and developing countries”, World

Bank, https://openknowledge.worldbank.org/handle/10986/3339 (accessed May 5, 2021).

[24] Grace M. F., Hotchkiss J. L., "External impacts on the property-liability insurance cycle,” Journal of Risk and
Insurance, vol. 6, no. 4, pp. 738-754, 1995. DOI: $10.2307 / 253593$

[25] Haiss P., Sümegi K., “The relationship between insurance and economic growth in Europe: A theoretical and empirical analysis,” Empirica, vol. 35, no. 4, pp. 405-431, 2008. DOI:10.1007/s10663-008-9075-2

[26] Hamwi I., Hudson T., Chen B., "Solvency regulation in the property-liability insurance industry," International Advances in Economic Research, vol. 10, no. 4, pp. 313-327, 2004. DOI: 10.1007/BF02295144

[27] Han L., Li D., Moshirian F., Tian Y., "Insurance development and economic growth," The Geneva Papers on Risk and Insurance-Issues and Practice, vol. 35, no. 2, pp. 183-199, 2010. DOI:10.1057/gpp.2010.4

[28] Hofflander A. E., Duvall R., "Inflation and sales of life insurance,” The Journal of Risk and Insurance, vol. 34, no. 3, pp. 355-361, 1967. DOI: 10.2307/250850

[29] Hunter J., Burke S., Canepa A., (2017). "Multivariate Time Series," and " Testing for Cointegration: Standard and Non-Standard Conditions," in Multivariate Modelling of Non-Stationary Economic Time Series (2 ed.), Palgrave Macmillian 2017, pp. 22-41 and pp. 189-191.

[30] Hwang T., Greenford B., “A cross-section analysis of the determinants of life insurance consumption in Mainland China, Hong Kong, and Taiwan,” Risk Management and Insurance Review, vol. 8, no. 1, pp. 103-125, 2005. DOI:10.1111/j.1540-6296.2005.00051.X

[31] Ibiwoye A., Ideji J., Babatunde O., “The determinants of life insurance consumption in Nigeria: A co- integration approach,” Academic Research International, vol. 2, no. 4, pp. 351-358, 2010.https://www.researchgate.net/publicatio n/327824449_THE_DETERMINANTS_OF_LIFE_INSU RANCE_CONSUMPTION_IN_NIGERIA_A_CO-INTER GRATION_APPROACH

[32] Jeng V., "Competition and its variation over time: An empirical analysis of the Chinese insurance industry," The Geneva Papers on Risk and Insurance-Issues and Practice, vol. 40, no. 4, pp. 632-652, 2015. https://www.jstor.org/sta ble/24736694

[33] Johansen S., "Statistical analysis of cointegration vectors," Journal of Economic Dynamics and Control, vol. 12, no. 2-3, pp. 231-254, 1988.DOI:10.1016/0165-1889(88)90041 $-3$

[34] Kjosevski J., Petkovski M., “The determinants of non-life insurance consumption: A VECM analysis in Central and South-Eastern Europe,” Acta Oeconomica, vol. 65, no. 1, pp. 107-127, 2015. DOI:10.1556/aoecon.65.2015.1.6

[35] Kjosevski J., "The determinants of life insurance demand in central and southeastern Europe," International Journal of Economics and Finance, vol. 4, no. 3, pp. 237-247, 2012. DOI:10.5539/ijef.v4n3p237

[36] Lamm-Tennant J., Weiss M., "International insurance cycles: Rational expectations/institutional intervention," The Journal of Risk and Insurance, vol. 64, no. 3, pp. 415-439, 1997. DOI:10.2307/253758

[37] Lee C.-C., Chiu Y.-B., "The impact of real income on insurance premiums: Evidence from panel data," 
International Review of Economics \& Finance, vol. 21, no. 1, pp. 246-260, 2012. DOI:10.1016/j.iref.2011.07.003

[38] Lee C.-C., Chang C.-H., Arouri M., Lee C.-C., “Economic growth and insurance development: The role of institutional environments,” Economic Modelling, vol. 59, no. C, pp. 361-369, 2016. DOI:10.1016/j.econmod.2016.08.010

[39] Lenten L., Rulli D., “A time-series analysis of the demand for life insurance companies in Australia: An unobserved components approach,” Australian Journal of Management, vol. 31, no. 1, pp. 41-66, 2006. DOI:10.1177/031289620603100104

[40] Levine R.,“Law, finance, and economic growth,” Journal of Financial Intermediation, vol. 8, no. 1-2, pp. 8-35, 1999. DOI:10.1006/jfin.1998.0255

[41] Levine R., Loayza N., Beck T., "Financial intermediation and growth: causality and causes,” Journal of Monetary Economics, vol. 46, no. 1, pp. 31-77, 2000. DOI:10.1016/S0304-3932(00)00017-9

[42] Li D., Moshirian F., Nguyen P., Wee T., "The demand for life insurance in OECD countries," Journal of Risk and Insurance, vol. 74, no. 3, pp. 637-652, 2007. https://www.jstor.org/stable/25145237

[43] Ling T., Shi-Jie J., Guochen P., Ning Zh., "Non-life insurance price dynamics: Evidence from the chinese insurance market," Economic Research-Ekonomska Istraživanja, vol. 31, no. 1, pp. 171-187, 2018. DOI:10.1080/1331677X.2018.1424557

[44] Luciano E., Outreville J., Rossi, M., "Life insurance ownership by italian households: A gender-based differences analysis," The Geneva Papers on Risk and Insurance-Issues and Practice, vol. 41, no. 3, pp. 468-490, 2016.

http://www.palgrave-journals.com/gpp/journal/v41/n3/pdf/ gpp20167a.pdf

[45] Lütkepohl H., Kratzig M., "Vector Autoregressive and Vector Error Correction Models" in Applied Time Series Econometrics. Cambridge University Press, 2004, pp. 86-131.

[46] Lütkepohl H., Saikkonen P., Trenkler C., "Maximum eigenvalue versus trace tests for the cointegrating rank of a VAR process,” The Econometrics Journal, vol. 4, no. 2, pp. 287-310, 2001. DOI:10.1111/1368-423X.00068

[47] Mantis G., Farmer R., "Demand for life insurance,” Journal of Risk and Insurance, vol. 35, no. 2, pp. 247-256, 1968. DOI:10.2307/250834

[48] Nesterova D., "Determinants of the demand for life insurance: Evidence from selected CIS and CEE countries." National University "Kyiv-Mohyla Academy": https://kse.ua/wp-content/uploads/2019/03/nesterova.pdf (accessed February 02, 2021).

[49] Neumann S., "Inflation and saving through life insurance," The Journal of Risk and Insurance, vol. 36, no. 5, pp. 567-582, 1969. DOI:10.2307/251163

[50] Neusser K., (2016). “Cointegration,” in Time Series Econometrics, Springer International Publishing, 2016, pp295-324.

[51] Novović Burić M., Cerović Smolović J., Lipovina Božović
M., Lalević Filipović A., "Impact of economic factors on life insurance development in Western Balkan Countries," Proceedings of Rijeka Faculty of Economics, Journal of Economics and Business, vol. 35, no. 2, pp. 331-352, 2015. DOI:10.18045/zbefri.2017.2.331

[52] Outreville J.-F., “Dépenses d'assurances, primes encaissées: Une approche macroéconomique,” The Geneva Papers on Risk and Insurance, vol. 5, no. 17, pp. 23-44, 1980. https://www.jstor.org/stable/41949984

[53] Outreville J-F., "The economic significance of insurance markets in developing countries," Journal of Risk and Insurance, vol. 57, no. 3, pp. 487-498, 1990. DOI: $10.2307 / 252844$

[54] Outreville J-F., "Life insurance markets in developing countries," Journal of Risk and Insurance, vol. 63, no. 2, pp. 263-278, 1996. DOI:10.2307/253745

[55] Outreville, J-F., "Insurance and Economic Development," in Theory and Practice of Insurance, Springer, 1998, pp. 15-28.

[56] Outreville J-F., “The relationship between insurance and economic development: 85 empirical papers for a review of the literature,” Risk Management and Insurance Review, vol. 16, no. 1, pp. 71-122, 2012. DOI:10.1111/j.1540-6296 .2012.01219.x

[57] Outreville J-F., "Culture and life Insurance ownership: Is it an issue?,” Journal of Insurance Issues, vol. 41, no. 2, pp. 168-192, 2018. https://www.jstor.org/stable/26505753

[58] Pesaran M., "Estimation of Stationary Time Series Processes," in Time Series and Panel Data Econometrics, Oxford University Press, 2015 pp. 297-313.

[59] Poposki K., Kjosevski J., “The determinants of non-life insurance demand in Central and South Eastern Europe. An empirical panel investigation," Horizons International Scientific Magazine. Series A, Social Sciences and Humanities, vol. 13, no. 1, pp. 131-151, 2014. https://www.uklo.edu.mk/filemanager/Horizonti/HORIZO NS\%20vol.XIII.pdf

[60] Poposki K., Kjosevski J., Stojanovsk Z., “The determinants of non-life insurance penetration in selected countries from South Eastern Europe," Economics and Business Review, vol. 15, no. 3, pp. 20-37, 2015. DOI:10.18559/ebr.2015.3.3

[61] Pradhan R., Dash S., Maradana R. P., Jayakumar M., Gaurav K., "Insurance market density and economic growth in Eurozone countries: The granger causality approach," Financial Innovation, vol. 3, no. 17, pp. 1-24, 2017. DOI:10.1186/s40854-017-0065-x

[62] Sen S., Madheswaran S., "Regional determinants of life insurance consumption: evidence from selected Asian economies,” Asian Pacific Economic Literature, vol. 27, no. 2, pp. 86-103, 2013. DOI:10.1111/apel.12024

[63] Sharku G., Shehu S., "Concentration of Albanian insurance market," Ekonomika a Management, vol. 2016, no. 3, 2016. http://www.vse.cz/eam/279

[64] Sherden W., "An analysis of the determinants of the demand for automobile insurance,” The Journal of Risk and Insurance, vol. 51, no. 1, pp. 49-62, 1984. DOI:10.2307/252800 
[65] Skipper H., "The Role of Insurance in Economic Development," in Foreign Insurers in Emerging Markets: Issues and Concerns, vol. 1, International Insurance Foundation, 1997, pp. 6-15.

[66] Staib D., Rodrigues C. S., Kubli D., Dornigg J., "World insurance: Riding out the 2020 pandemic Storm.” Swiss Re Institute.

https://www.swissre.com/institute/research/sigma-research /sigma-2020-04.html (accessed June 30, 2021).

[67] Ventzislav I., Lutz K., “A practitioner's guide to lag-order selection for vector autoregressions.” Center for Economic and Policy Research Discussion Papers 2685. https://cepr.org/active/publications/discussion_papers/dp.p hp?dpno=2685 (accesed June 9, 2021)

[68] Ward D., Zurbruegg R., "Law, politics and life insurance consumption in Asia," The Geneva Papers on Risk and Insurance, vol. 27, no. 3, pp. 395-412, 2002. DOI:10.1111/1468-0440.00181

[69] Webb I., Grace M., Skipper H.,"The effect of banking and insurance on the growth of capital and output," Journal of Financial Issues SBS, vol. 2, no. 2, pp. 1-32, 2005.
https://www.sbs.gob.pe/Portals/0/jer/EDIPUB_VOLUME N2NB/1Grace.pdf

[70] Yuan C., Yu J., "Factors affecting the demand for insurance in China," Applied Economies, vol. 47, no. 45, pp. 4855-4867, 2015. DOI:10.1080/00036846.2015.1037437

[71] Zerriaa M., Noubbigh H., "Determinants of life insurance demand in the MENA Region,” The Geneva Papers on Risk and Insurance-Issues and Practice, vol. 41, no. 3, pp. 491-511, 2016. DOI:10.1057/gpp.2016.1

[72] Zerriaa M., Amiri M. M., Noubbigh H., Naoui K., "Determinants of life insurance demand in Tunisia," African Development Review, vol. 29, no. 1, pp. 69-80, 2017. DOI: $10.1111 / 1467-8268.12239$

[73] Zietz E., "An examination of the demand for life insurance," Risk Management and Insurance Review, vol. 6, no. 2, pp. 159-191, 2003. DOI:10.1046/J.1098-1616.2003.030.x

[74] Zykaj E., Myftaraj-Tomori E.,"Factors affecting the insurance sector development: Evidence from Albania," The Romanian Economic Journal, vol. 17, no. 51. pp. 171-188, 2014. http://www.rejournal.eu/sites/rejournal.ver satech.ro/files/articole/2014-03-01/1898/8zyka.pdf 